\title{
Residual characteristics and processing factors of azoxystrobin during eggplant and lettuce processing
}

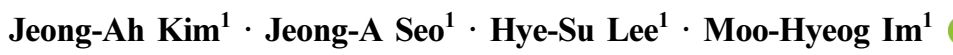 \\ 가지와 상추의 가공 중 azoxystrobin의 잔류량 변화 및 가공계수
}

김정아 · 서정아 · 이혜수 · 임무혁

Received: 30 December 2019 / Accepted: 4 February 2020 / Published Online: 31 March 2020

(C) The Korean Society for Applied Biological Chemistry 2020

\begin{abstract}
This study was conducted to investigate changes in pesticide residues in eggplant and lettuce during washing and cooking processes after application with azoxystrobin. Eggplant was processed with running washing, steaming, and stir-frying, and lettuce was processed with soaking washing, running washing, soaking and running washing, ultrasonic cleaning, and blanching. The limit of quantitation of GC analysis of azoxystrobin was 0.01 $\mathrm{mg} / \mathrm{kg}$ and the recovery rate was $84.7-109.5 \%$. The azoxystrobin processing factors (PFs) and reduction rates in eggplant and lettuce were calculated and the results were as follows. In the case of eggplant, the azoxystrobin PF and reduction rate of running washing were 0.29 and $71.1 \%$, respectively, those of steaming were 0.32 and $68.0 \%$, respectively, and those of stir-frying were 0.24 and $75.7 \%$, respectively. In the case of lettuce, the azoxystrobin $\mathrm{PF}$ and reduction rate of soaking washing were $0.25,75.3 \%$, those of running washing were 0.61 and $38.9 \%$, respectively, those of soaking and running washing were $0.32,68.0 \%$, those of ultrasonic cleaning were 0.47 and $53.1 \%$, respectively, and those of blanching were 0.26 and $73.6 \%$, respectively. It could be identified that pesticide residues in eggplant and lettuce can be effectively reduced through washing and cooking processes and that most of pesticide
\end{abstract}

Moo-Hyeog $\operatorname{Im}(\bowtie)$

E-mail:imh0119@daegu.ac.kr

${ }^{1}$ Department of Food Engineering, Daegu University, Gyeongbuk, Republic of Korea

This is an Open Access article distributed under the terms of the Creative Commons Attribution Non-Commercial License (http://creativecommons. org/licenses/by-nc/3.0/) which permits unrestricted non-commercial use, distribution, and reproduction in any medium, provided the original work is properly cited. residues were removed when cooking processes were undergone after washing. Therefore, azoxystrobin PFs after washing and processing can be provided as basic data for risk assessment.

Keywords Azoxystrobin · Eggplant · Lettuce · Processing factor Pesticide residue

\section{서 론}

농약은 농산물의 재배, 저장 중 발생하는 병 - 해충을 방제하는 데 사용하는 화학 농약 및 생물 농약을 말하며, 작용 효과에 따 라 살균제, 제초제, 살충제, 살비제, 살선충제 등으로 분류된다 [1,2]. 농약의 사용으로 생산성 향상, 농산물의 품질향상, 노동력 절감의 효과를 나타내지만, 소비자들에게는 식품 중 잔류농약 및 환경오염과 같은 부정적인 측면이 더 부각되고 있다[3]. 화 학물질과 관련된 여러 가지 사건사고가 발생하면서 케미포비아 (Chemiphobia)라는 합성어가 생길 정도로 소비자들의 화학물질 에 대한 두려움과 선입견이 커졌으며, 특히 식품과 관련된 화 학물질에 대한 불안감은 높은 수준이다[4]. 따라서 정부에서는 잔류농약 안전성 강화를 위하여 농산물 생산이력제를 도입하여 농산물의 생산과정에 사용된 농약성분을 공개하도록 하고 있으 며, 우수농산물관리제도(Good Agricultural Practices, GAP)로 농산물의 생산단계에서 판매단계까지의 생물학적, 화학적 위해 요소를 중점적으로 관리하는 제도를 도입하여 농산물의 안전성 을 확보하였다[5]. 농작물 재배시 안전한 농약 사용을 위하여 농작물별 농약안전사용기준을 정하고, 국민이 평생 매일 섭취하 여도 인체에 해를 끼치지 않는 수준의 농약잔류허용기준(Maximum Residue Limit, MRL)을 설정하여 관리하고 있다. 또한 2019년 1 월부터 잔류허용기준이 설정되지 않은 농약에 대해 불검출 수 
준인 $0.01 \mathrm{ppm}$ 으로 기준을 제한하는 농약허용물질목록 관리제 도(Positive List System, PLS)가 도입되어 기준초과 시, 유통 금지가 되는 강력한 규제를 하고 있다[1,6,7]. 농약 등록 및 농 약잔류허용기준 설정을 위해서 농약 회사 등에서는 농약에 대 한 급성, 아급성, 아만성, 만성 등의 독성 자료, 농산물의 농약 잔류자료, 식품 가공 중 농약 가공계수 자료 등을 정부기관에 제출하여야 된다. 이러한 자료를 평가하여 농약의 일일 섭취허 용량(Acceptable Daily Intake, $\mathrm{ADI}$ )을 설정하고 $\mathrm{ADI}$ 를 이용하 여 식품 중 농약의 $\mathrm{MRL}$ 을 설정한다. 농민들은 농작물 재배 시 MRL이 설정된 농약을 사용할 수 있게 된다[8].

농산물 원료에 잔류된 농약은 조리, 가공 중 세척, 열 분해, 휘발 등으로 대부분 감소되지만, 지용성 또는 비휘발성 농약은 건조나 농축과정 중에 원료보다 높게 잔류되기도 한다[9-20]. 우 리나라의 경우, 농약 잔류허용기준은 조리·가공 중 농축되는 경우에 농산물 원료와 농축된 가공식품에 대하여 각각 기준설 정을 한다[21]. 현재 식품의약품안전처는 식품 중 농약의 $\mathrm{MRL}$ 설정 시 대부분의 경우 원료 농산물에 대하여 제출된 농약 잔 류자료로부터 제안된 기준(안)과 국민 평균 식품섭취량을 이용 하여 $\mathrm{ADI}$ 를 초과하지 않도록 농약기준치를 이론적인 섭취량 평 가(Theoretical Maximum Daily Intake, TMDI)를 통하여 설정 하고 있다 $[1,8]$. 국제식품규격위원회 농약전문가위원회(Joint meeting FAO/WHO on Pesticides Residues, JMPR)에서는 $\mathrm{TMDI}$ 평가가 아닌 감독하의 잔류시험 중간 잔류값(Supervised Trial Medium Residue, STMR)과 식품 섭취량을 이용한 추정 섭취량(Estimated Daily Intake, EDI)으로 위해 평가를 실시한 후, 농산물에 대한 기준을 제안하고 가공식품은 원료 가공 후 농약이 농축되거나, 다량 감소된 경우 기준을 제안한다. 또한, 가공식품의 기준을 제안하지 않은 가공계수는 EDI 평가시 STMR에 곱하여 활용하고 있다. 그래서 Codex에 농약 기준 설 정을 위하여 농약회사에서 $\mathrm{JMPR}$ 에 잔류자료를 제출할 경우, 가 능한 가공계수 연구자료(Processing study)를 제출하고, JMPR에 서는 이 자료를 활용하여 가공계수를 제안하며 실제에 가까운 추정량으로 현실적인 위해 평가에 활용하고 있다[7]. 그러나 우 리나라에서는 이러한 가공계수 연구자료가 거의 제출되지 않기 때문에 가공연구 자료를 위해 평가에 활용하지 못하고 있다.

보건복지부에서 발간한 2017년 국민건강영양조사 결과 중 우리 나라의 식품 섭취패턴에서 섭취량이 높은 식품군은 곡류(288.5 g), 채소류(283.2 g), 과일류(161.9 g)로 채소류는 2번째로 섭취량이 높은 식품군이었다[22-23]. 소비자들은 다양한 채소류를 다량 섭 취하며, 이 채소류 중 상추와 가지의 섭취량은 높은 편이다[2223].

국내에서 채소류에 대하여 수행된 가공연구는 인삼 가공[13$15,17,24]$, 배추 가공[25-26], 고추 가공[27-29], 파, 시금치, 미 나리 등 엽채류 가공[3,11,30-32], 건조 가공[19,20,33] 등이 있 으며 가공연구 내용은 채소류의 전처리 및 가공 중 농약잔류량 변화에 대한 연구가 보고되었다.

엽채류 중 상추에 대한 가공연구 자료와 박과 이외의 과채류에 대한 농약 감소에 대한 연구를 살펴보면, Itoiz 등은 azoxystrobin과 imidacloprid를 살포한 상추의 잔류량에 대한 연구 중 세척을 통 하여 약 $50 \%$ 가 감소하였다고 보고하였으나 상추 세척 방법과 세척 후 잔류농약 감소결과 자료는 확인할 수 없었다[34]. Camara 등은 상추에 imidacloprid, tebufenozide, metalaxil, tebuconazole, cypermethrin, azoxystrobin을 살포한 후 절단하여 $100 \mathrm{ppm}$ sodium hypochlorite 세척 후 비닐팩으로 포장하여 신 선편이식품으로 가공하였으며, 이때 농약의 평균 가공계수가 0.47 로 약 $53 \%$ 의 잔류농약이 제거되었다고 보고하였다[35]. Fenoll 등은 procymidone과 azoxystrobin을 살포한 후 냉동보관 하여 저장 중 잔류량 감소를 연구하였다[36]. Rodrigues 등은 박과 이외의 과채류인 토마토에 azoxystrobin, chlorothalonil, difenoconazole을 살포한 후 물, acetic acid, sodium bicarbonate, sodium hypochlorite 용액에 침지시킨 후 농약 감소효과를 측정 하여, 물 세척은 azoxystrobin $26 \%$, chlorothalonil $44 \%$, difenoconazole $17 \%$ 였으며, 이외 용액에 침지할 경우 최대 $83 \%$ 의 제거효율을 나타났다고 보고하였다[37]. 상기 연구들과 같이 채소류 중 상 추에 대한 azoxystrobin 농약의 세척에 따른 잔류농약 감소 연 구는 그 결과가 미비하거나, 상업적인 전처리 또는 냉동보관 중 농약 잔류량의 변화에 한정되었으며, 일반 가정에서의 세척방법 에 따라서 잔류농약 감소효과에 대하여 비교한 연구는 거의 찾 아볼 수 없었다. 또한 가지에 대한 azoxystrobin 농약의 감소효 과 연구는 찾아볼 수 없었으며, 가공 중 영양소 변화 등에 대 한 연구가 보고 되었다[38,39].

가지에 주로 발생되는 병해충은 점박이응애, 탄저병, 흰가루 병, 갈색무늬병 등이 있으며[40], 현재 가지에는 132 개의 농약 에 대하여 농약잔류허용기준(MRL)이 설정되어 있다[21]. 상추 의 병해는 시들음병, 노균병, 흰가루병, 균핵병, 잿빛곰팡이병, 세균성점무늬병 등이 있으며[40], 상추에 99개의 농약에 대한 $\mathrm{MRL}$ 이 설정되어 있다[21]. 상추와 가지에 MRL이 설정된 성분 중 흰가루병을 방제하는 azoxystrobin은 strobilurin계 살균제로 서 110 종의 농산물에 잔류허용기준이 설정되어 있으며[21], 전 자전달을 막아 미토콘드리아에서의 호흡을 저해하는 농약이다. 이 농약은 여러 종류의 병해에 대한 예방 효과와 치료 효과를 나타내고, 침투이행성이 있어서 작물에 잔류할 가능성이 높은 농약이다[41]. 식품의약품안전처의 2012-2016년 국내 유통 식품 중 잔류농약 모니터링 결과에 따르면 전체 165,520 건을 검사하 여 1154 건의 농산물이 기준을 초과하였으며, 이 중 과일류 613 건, 채소류는 474건이었다. 이 1154건의 부적합 중 azoxystrobin 은 41건으로 조사되어 비교적 부적합률이 높은 농약으로 판단 된다[42].

Azoxystrobin은 다양한 농산물의 병해충 방제에 사용되며, 국 내 유통 식품 잔류농약 모니터링에서 자주 검출되는 부적합률 이 높은 농약이다. 또한 식품의 가공 중 잔류농약 가공연구를 통하여 잔류량 변화, 가공계수를 조사할 경우, 실제 잔류농약 섭취에 대한 위해평가의 기초자료로 활용할 수 있다. 국내에는 인삼, 배추, 고추, 파, 시금치, 미나리 등 다양한 채소류의 가공 연구가 진행되어 위해평가의 기초자료로 활용가능하나, 상추와 가지는 섭취량이 비교적 높은 편인 농산물임에도 불구하고 실 제 위해평가를 위해서는 농약 가공연구 자료가 부족한 실정이다. 따라서 본 연구에서는 상추와 가지의 보편적인 가공에 의한 잔 류량 변화를 조사하여 위해평가의 기초자료로 활용하기 위하여 국내 부적합률이 높은 azoxystrobin을 대상농약으로 가공연구 결 과가 부족한 가지와 상추를 시료로 선택하였다. 재배지에서 azoxystrobin을 살포한 가지와 상추를 채취하여 세척과 조리과 정을 통한 농약의 잔류량변화를 분석하여 가공과정에 따른 농 약의 제거효율과 가공계수를 산출하고자 하였다. 


\section{재료 및 방법}

\section{농산물 및 시험농약}

Azoxystrobin의 표준품(99.8\%)은 Dr. Ehrenorfer $\mathrm{GmbH}$ (독일) 의 제품을 사용하였다. 가지와 상추의 시험 포장은 경상북도 김 천시 감문면에 위치한 시설재배 하우스를 임대하여 실시하였다. 흰가루병 방제에 사용되고 있는 살균제 azoxystrobin $21.7 \%$ 액 상수화제를 2,000 배 희석하여 가지는 $250 \mathrm{~L} / 10 \mathrm{a}$ 비율로 전동식 배부식 분무기를 이용하여 수확 3일전 3회 살포하였으며, 상추 는 $200 \mathrm{~L} / 10 \mathrm{a}$ 의 비율로 수확 7일전 2회 살포하여 수확하였다. 채취된 시료는 균질화한 후 잔류농약 분석까지 $-20{ }^{\circ} \mathrm{C}$ 의 냉동 고에 보관하여 1 개월 이내에 분석하였다. 시험농약의 구조 및 이화학적 특성을 Table 1에 나타내었다[43].

\section{가지와 상추의 세척 및 조리}

가지와 상추의 가공방법에 따른 azoxystrobin의 잔류량 변화를 확인하기 위해 세척 및 조리과정을 수행하였다. 가지의 가공방 법은 흐르는 물 세척, 찌기 및 데침 과정을 진행하였고, Fig. 1
에 요약하여 제시하였다. 상추의 가공방법은 담금 물 세척, 담 금 후 흐르는 물 세척, 흐르는 물 세척, 초음파 세척 및 데침 과정을 진행하였고, Fig. 2에 요약하여 제시하였다. 가공을 통 한 잔류량 변화를 알아보기 위해 실제 가정에서 많이 사용하는 가공과정을 진행하였다. 가공을 마친 시료는 균질화시킨 후 잔 류농약 분석 직전까지 $-20{ }^{\circ} \mathrm{C}$ 의 냉동고에 보관하였다.

가지와 상추의 세척방법은 일반가정에서 사용하는 세척 방법 을 준용하여 진행하였다[44,45]. 가지의 흐르는 물 세척은 가지 를 흐르는 물에서 6초간 가볍게 흔들면서 세척을 진행하였다. 세척한 가지 시료를 채반에 담아 1 시간 동안 물기를 충분히 제 거한 후 비가식 부위를 제거하였다. 찌기 및 볶음은 Ko 등의 연구[38]와 Park 등의 가지 조리조건에 따른 연구[39]를 참고하 여 일반적인 방법을 사용하여 진행하였다. 찌기는 흐르는 물에 세척하여 중력수를 제거한 가지 $400 \mathrm{~g}$ 을 $3 \mathrm{~cm}$ 두께로 자른 후 증류수 $1 \mathrm{~L}$ 가 담겨있는 냄비 속에 찜기를 받혀 담고 뚜껑을 닫 고 6 분간 조리하여, 찐 가지 시료를 채반에 담아 1시간 동안 냉각 및 탈수시켰다. 볶음은 흐르는 물에 세척하여 중력수를 제 거한 가지 $400 \mathrm{~g}$ 을 $3 \mathrm{~cm}$ 두께로 자른 후 식용유 $8 \mathrm{~mL}$ 를 담아

Table 1 Chemical structure and physico-chemical properties of azoxystrobin

Chemical Structure<smiles>CO/C=C(/C(=O)OC)c1ccccc1Oc1cc(Oc2ccccc2C#N)ncn1</smiles>

\begin{tabular}{cl}
\hline IUPAC name & Methyl(E)-2-\{2-[6-(2-cyanophenoxy)pyrimidin-4-ylmethoxy]phenyl\}-3-methoxyacryltate \\
Molecular formula & $\mathrm{C}_{22} \mathrm{H}_{17} \mathrm{~N}_{3} \mathrm{O}_{5}$ \\
$\mathrm{P}_{\mathrm{OW}}$ & $2.5\left(20^{\circ} \mathrm{C}\right)$ \\
Vapor pressure & $1.1 \times 10^{-7}\left(20^{\circ} \mathrm{C}\right) \mathrm{mPa}$ \\
Solubility in water & $6.7(\mathrm{pH} 7)$ \\
Melting point & $116^{\circ} \mathrm{C}$ \\
Stability & $\mathrm{DT}_{50}$ aqueous photolysis 2 week. Stable to hydrolysis at pH5-7 and room temperature. \\
Mode of action & Fungicide with protectant, curative, eradicant, translaminar and systemic properties. \\
& Inhibits spore germination and mycelial growth, and also shows antisporulant activity. \\
\hline
\end{tabular}

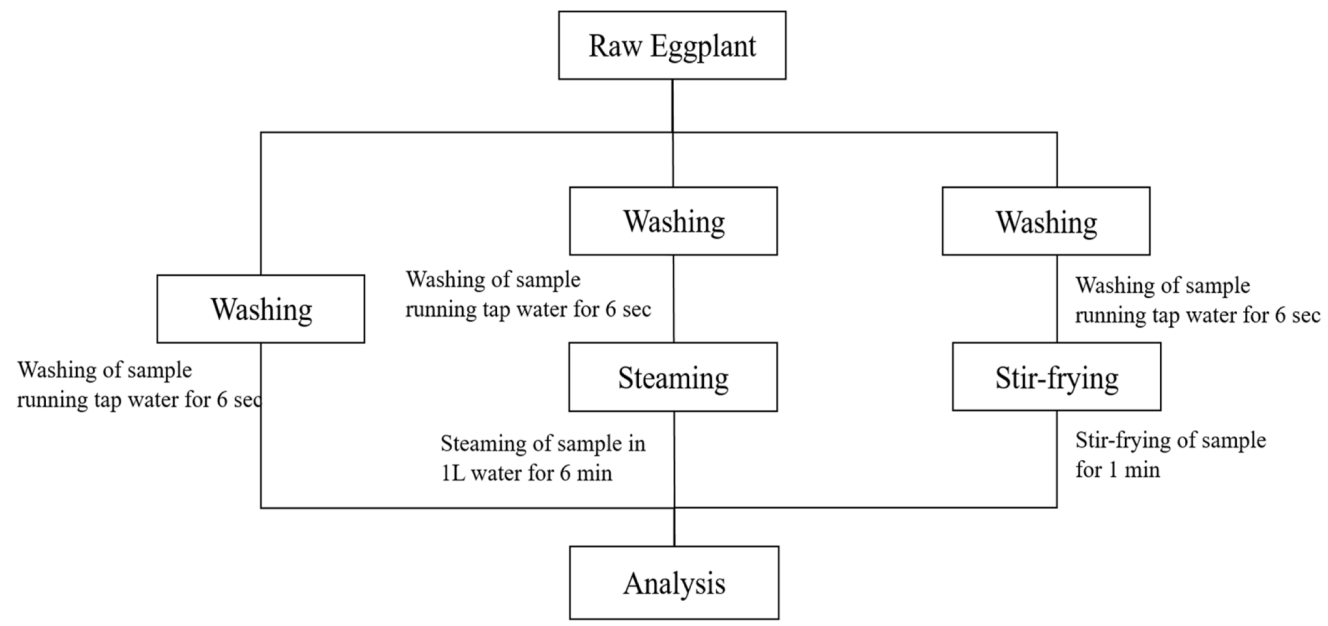

Fig. 1 The processing flow diagram of eggplant 


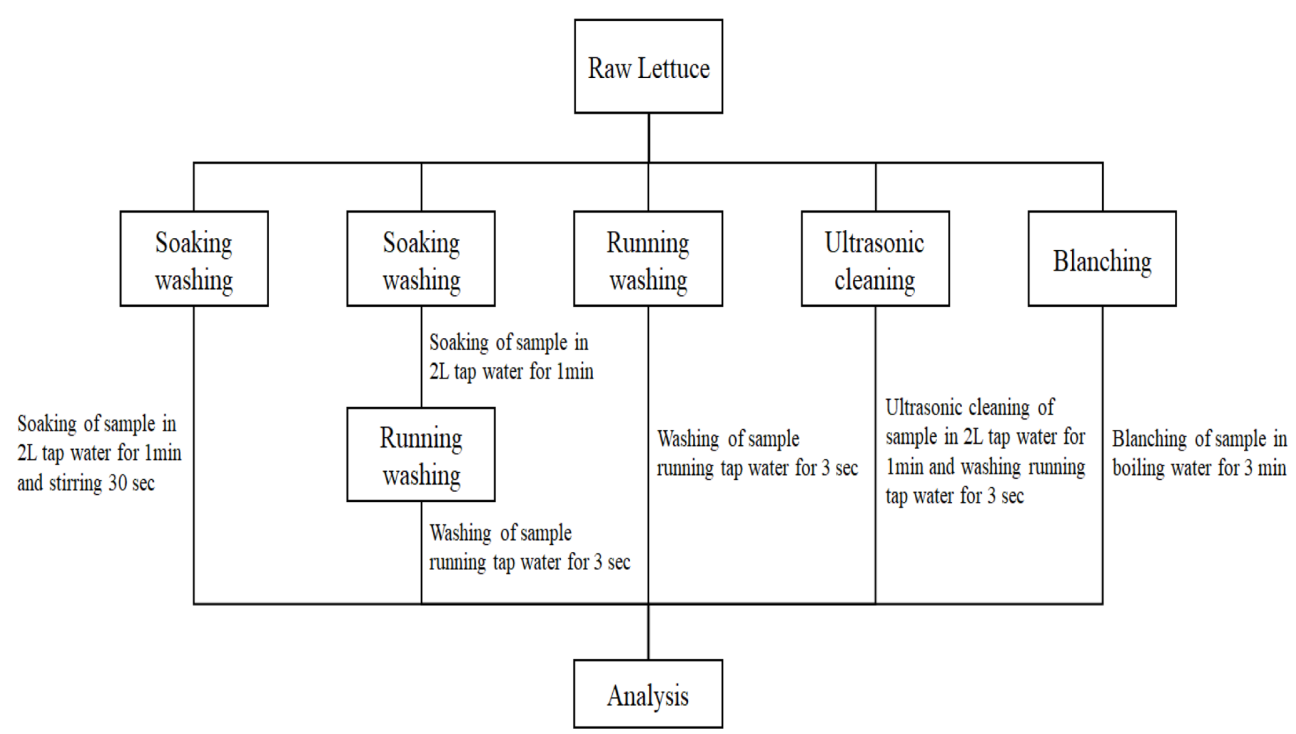

Fig. 2 The processing flow diagram of lettuce

가열한 팬에 시료를 넣고 1 분간 볶아서 1 시간 동안 냉각시켰다. 상추의 담금 물 세척은 매스실린더로 칭량된 수돗물 $2 \mathrm{~L}$ 를 스테인레스 용기에 담고 상추 $120 \mathrm{~g}$ 을 침지시켜 1 분 동안 담근 후 물은 버리고, 같은 양의 새 물로 30 초 동안 손으로 저어주 면서 2회 세척하였다. 세척한 상추 시료를 가볍게 흔들어 물기 를 제거한 후 채반에 담아 1 시간 동안 물기를 제거하였다. 담 금 후 흐르는 물 세척은 매스실린더로 칭량된 수돗물 $2 \mathrm{~L}$ 를 스 테인레스 용기에 담고 상추 $120 \mathrm{~g}$ 을 침지시켜 1 분 동안 담근 후 손으로 저어주면서 세척한 후 물은 버리고, 흐르는 물에 한 장씩 앞, 뒷면을 3 초 세척하였다. 세척한 상추 시료를 가볍게 흔들어 물기를 제거한 후 채반에 담아 1 시간 동안 물기를 제거 하였다. 흐르는 물 세척은 상추를 흐르는 물에서 한 장씩 3 초 간 앞, 뒷면을 가볍게 흔들면서 세척을 진행하였다. 세척한 상 추 시료를 채반에 담아 1 시간 동안 물기를 충분히 제거하였다. 초음파 세척은 매스실린더로 칭량된 수돗물 $2 \mathrm{~L}$ 를 초음파 세척 기에 담고 상추 $120 \mathrm{~g}$ 을 침지시켜 1 분 동안 초음파 세척한 후, 흐르는 물에 한 장씩 앞, 뒷면을 3 초 세척하였다. 세척한 상추 시료를 가볍게 흔들어 물기를 제거한 후 채반에 담아 1 시간 동 안 물기를 제거하였다. 상추는 데쳐서 섭취하는 경우가 거의 없 으나 엽채류의 데치기 효과를 보기 위해서 세척과정을 거치지 않고 데침 과정을 진행하였다. 데침은 Jung의 시금치 가공연구 [31] 및 $\mathrm{Kim}$ 등의 가공연구[3]를 참고하여 진행하였다. 매스실 린더로 칭량된 수돗물 $1.2 \mathrm{~L}$ 를 냄비에 담고 가열하여 물이 끓 은 후 시료를 넣고 3 분 동안 데치기를 진행하였다. 데친 상추 시료를 채반에 담아 1 시간 동안 냉각 및 탈수시켰다.

\section{잔류농약 분석}

가공 전후의 가지와 상추 시료 중 azoxystrobin의 분석법은 다 음과 같으며, 이를 요약하여 Fig. 3에 나타내었다. Azoxystrobin 은 Gas Chromatography-Electron Capture Detector (GC-ECD) 로 Table 2와 같은 조건으로 분석하였다.

각 처리구별로 채취한 시료 $30 \mathrm{~g}$ 에 acetone $70 \mathrm{~mL}$ 를 첨가한 후 homogenizer에서 $14,000 \mathrm{rpm}$ 으로 1 분간 고속마쇄, 추출하였다.

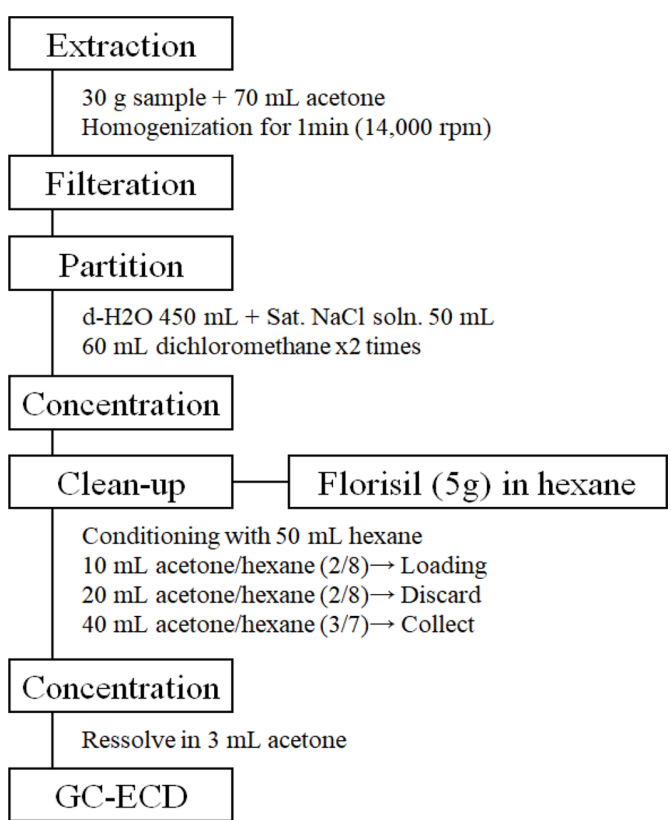

Fig. 3 The flow diagram for residue analysis of the azoxystrobin in eggplant and lettuce

추출물은 $9 \mathrm{~cm}$ 여과지가 깔린 Buchner funnel상에서 celite 545 를 통과시켜 흡인여과하고 $30 \mathrm{~mL}$ 의 acetone을 이용하여 용기 및 잔사를 씻어 앞의 여액과 합하였다. 이 여액을 $1.0 \mathrm{~L}$ separatory funnel에 옮겨 증류수 450 과 $50 \mathrm{~mL}$ 의 포화식염수를 가하고 $60 \mathrm{~mL}$ 의 dichloromethane으로 2 회 분배 추출하였다. Dichloromethane 추출액을 anhydrous sodium sulfate 층에 통 과시켜 탈수하고 $40{ }^{\circ} \mathrm{C}$ 수욕조상에서 감압농축하였다. 시료 정 제를 위하여 column chromatography 방법이 수행되었다. Chromatographic glass column에 $120^{\circ} \mathrm{C}$ 에서 5시간 이상 활성 화시킨 florisil $5 \mathrm{~g}$ 과 anhydrous sodium sulfate $2 \mathrm{~g}$ 을 차례로 습식충진한 후 $50 \mathrm{~mL}$ 의 hexane으로 세척하여 column을 안정화 
Table 2 GC-ECD conditions for the analysis of azoxystrobin in eggplant and lettuce

\begin{tabular}{cl}
\hline Instrument & SHIMADZU GC-2010 system \\
Detector & ECD \\
Column & HP-ULTRA $1(50 \mathrm{~m} \mathrm{L.} \times 0.32 \mathrm{~mm} \mathrm{I.D.} \times 0.17 \mu \mathrm{m}$ film thickness $)$ \\
Column flow & He $(1.0 \mathrm{~mL} / \mathrm{min}$, constant flow $)$ \\
Inj. temp.\& Inj. mode & $250^{\circ} \mathrm{C}$, split mode $(50: 1)$ \\
Detector temp. & $310^{\circ} \mathrm{C}$ \\
Oven temp. & $240^{\circ} \mathrm{C}(5 \mathrm{~min})-10{ }^{\circ} \mathrm{C} / \mathrm{min}-310^{\circ} \mathrm{C}(15 \mathrm{~min})$ \\
Injection vol. & $1 \mu \mathrm{L}$ \\
Make up gas & $\mathrm{N}_{2}, 60 \mathrm{~mL} / \mathrm{min}$ \\
\hline
\end{tabular}

시켰다. 추출 후 농축된 시료를 $10 \mathrm{~mL}$ 의 acetone/hexane $(2 / 8$, $\mathrm{v} / \mathrm{v})$ 혼합용매로 재용해하여 정제과정에 사용하였다. 잔사를 흘 려버린 후, acetone/hexane $(2 / 8, \mathrm{v} / \mathrm{v})$ 혼합용매 $20 \mathrm{~mL}$ 로 유출시켜 버리고, acetone/hexane $(3 / 7, \mathrm{v} / \mathrm{v})$ 혼합용매 $40 \mathrm{~mL}$ 로 azoxystrobin 을 용출시켜 그 용출액을 분취하여 감압농축하였다. 농축된 잔 사를 acetone $3 \mathrm{~mL}$ 에 재용해하여 Table 2의 조건으로 $\mathrm{GC}$ $\mathrm{ECD}$ 에 주입하여 나타난 chromatogram 상의 peak area를 표준 검량선과 비교하여 잔류량을 산출하였다.

\section{가공계수 산출}

가공계수는 농산물 원료의 잔류량과 가공한 후의 잔류량의 비 를 나타내는 계수이며, 가지와 상추의 가공품의 가공계수는 아 래의 식을 이용하여 산출하였다.

가공계수(Processing Factor) $=\frac{\text { 가공품 중 농약 잔류량 }(\mathrm{mg} / \mathrm{kg})}{\text { 원료 중 농약 잔류량 }(\mathrm{mg} / \mathrm{kg})}$

\section{검량선 작성 및 재현성 검중}

Azoxystrobin standard (순도 99.8\%) $0.05 \mathrm{~g}$ 을 $50 \mathrm{~mL}$ 의 acetone 에 용해하여 $1,000 \mathrm{mg} / \mathrm{L}$ 의 stock solution을 제조하였으며, 이를 acetone에 희석하여 working solution을 조제하여 $1 \mu \mathrm{L}$ 을 $\mathrm{GC}$ $\mathrm{ECD}$ 에 주입하였다. 가지의 검량선은 $0.01,0.2,0.4,0.6,0.8$ $\mathrm{mg} / \mathrm{L}$ 의 working solution을 조제하였으며, 상추의 검량선은 $0.01,4,8,12,16 \mathrm{mg} / \mathrm{L}$ 의 working solution을 조제하였다. 조 제된 standard solution을 GC-ECD에 주입하여 나타난 chromatogram 상의 peak 면적을 이용하여 표준검량선을 작성하였다. 또한, 분 석기기의 재현성(reproducibility)을 검증하기 위해 $0.5 \mathrm{mg} / \mathrm{L}$ 의 azoxystrobin 표준용액을 $\mathrm{GC} / \mathrm{ECD}$ 에 10 회 연속주입하여 크로마 토그램 상의 retention time (Rt.) 및 peak area 등의 변이를 비 교 평가하였다.

\section{정량한계}

정량한계(limit of quantitation, LOQ)는 분석결과를 수치화할 수 있는 최저한계를 의미한다[46]. 분석 정량한계는 대조 농산물 시료에서 간섭물질이 존재하지 않음을 확인하고, 분석기기의 정 량한계, 시료 주입량, 시료 사용량 및 최종 회수된 시료 용액의 양을 계산하여 아래의 계산식에 의해 산출하였으며[47], 동일 수준으로 azoxystrobin을 처리한 주요 농산물의 회수율을 확인 하였다.
정량한계 $(\mathrm{mg} / \mathrm{kg})$

$=[$ 기기 정량한계 $(\mathrm{ng}) /$ 주입량 $(\mu \mathrm{L})] \times[$ 시료용액 $(\mathrm{mL}) /$ 시료량 $(\mathrm{g})]$

\section{액-액 분배 조건 확립}

농산물 시료로부터 azoxystrobin을 추출하기 위한 용매로는 acetone을 사용하였으며, acetone 추출 시 azoxystrobin과 함께 추출되는 매트릭스 성분을 제거하기 위해 액-액 분배법을 사용 하였다. 분배 용매로는 dichloromethane을 사용하였다. Azoxystrobin 의 분배효율을 조사하기 위해 농산물 시료 없이 표준품 용액만 을 acetone에 첨가한 후 dichloromethane 액-액 분배 시 분배 횟수를 달리하여 최적 조건을 확립하였다.

\section{흡착크로마토그래피 정제 조건 확립}

Azoxystrobin 분석 시 액-액 분배를 통하여 대부분의 극성 불순 물 및 비극성 간섭물질들이 일부 제거되지만, 농산물에 따라 시 료 매트릭스로부터 유래하는 다양한 불순물이 존재하기 때문에 추가적인 정제과정이 필요할 것으로 판단되어 흡착크로마토그 래피에 의한 정제법을 사용하였다. 흡착크로마토그래피 정제의 효율을 조사하기 위해 florisil을 흡착제로 선정하였다. Florisil에 흡착된 농약을 추출하는 최적 용매량을 결정하기 위하여 시료 없이 표준품만을 florisil에 흡착시킨 후 acetone과 hexane (7:3) 용매를 $10,20,30$ 과 $40 \mathrm{~mL}$ 로 그 양을 달리하여 최적 정제 조 건을 확립하였다.

\section{회수율 검증}

본 연구에서 확립된 azoxystrobin 분석법의 정확성 및 재현성을 검증하기 위해 실제 농산물 시료를 대상으로 회수율 검증 실험 을 수행하였다[46]. 회수율 실험은 농약 잔류성 시험기준 및 방 법[46]에 따라, 분쇄한 각 무농약 농산물 시료 $30 \mathrm{~g}$ 에 azoxystrobin 표준용액을 정량한계의 10 배 및 50 배에 해당하도록 표준용액을 3 반복으로 인위 첨가한 후 앞의 분석과정을 행하여 회수율과 분석오차를 검증하였다.

\section{결과 및 고찰}

\section{시료 중 azoxystrobin의 분배 및 정제조건 확립}

농산물 시료로부터 azoxystrobin을 추출을 위해 acetone을 이용하 여 추출하였다. Acetone은 이미 많은 연구자들에 의하여 농약 추 
Table 3 Efficiency of liquid-liquid partition for azoxystrobin

\begin{tabular}{ccccc}
\hline \hline \multirow{2}{*}{ Compound } & \multicolumn{4}{c}{ Recovery ratio (\%) } \\
\cline { 2 - 5 } & Partition I & Partition I & Partition III & Partition IV \\
\hline Azoxystrobin & $90.4 \pm 1.9$ & $98.5 \pm 1.3$ & $95.8 \pm 0.5$ & $101.9 \pm 1.4$ \\
\hline \multirow{3}{*}{$\begin{array}{c}\text { Table 4 Elution profile of azoxystrobin on florisil column chromatography } \\
\text { (v:v) }\end{array}$} & $10 \mathrm{~mL}$ & $20 \mathrm{~mL}$ & $30 \mathrm{~mL}$ & $40 \mathrm{~mL}$ \\
\hline \hline \multirow{2}{*}{\begin{tabular}{c} 
Elution Solvent \\
\cline { 2 - 5 }
\end{tabular}} & $81.5 \pm 0.9$ & $82.6 \pm 0.8$ & $89.9 \pm 0.5$ & $98.9 \pm 0.5$ \\
\hline acetone:hexane/3:7
\end{tabular}

출의 효율과 재현성이 인정되었으며, 농약의 추출에 흔히 사용되 는 용매다[48]. Acetone 추출 시, 농산물 추출액으로부터 azoxystrobin 과 함께 추출되는 시료의 매트릭스 성분을 제거하기 위한 1 차적 정제법으로 액-액 분배법을 사용하였다. 수용성 유기용매 추출액 을 다량의 포화식염수와 증류수로 희석한 후 직접 비극성 용매로 분배 추출하는 방법으로, $\mathrm{AOAC}$ 법 등에서 많이 사용되는 방법으 로 번거로운 추출액의 농축과정을 생략할 수 있는 장점이 있다 [49,50]. 액-액 분배법에 사용한 분배 용매는 dichloromethane을 사 용하여 azoxystrobin의 분배효율을 조사하여 Table 3에 나타내었다.

분배 횟수에 따른 분배효율을 조사한 결과, azoxystrobin은 dichloromethane 용액으로 분배하였을 때 회수율이 모두 $90 \%$ 가 넘는 결과를 보였으며, 2회 분배 시 $98.5 \%$ 의 회수율을 나타내 어 전량 회수되는 양상을 보였다. 분배 횟수를 늘려도 회수율 이 크게 향상되지 않았으므로, 작업의 편의성을 고려하여 비극 성 간섭물질의 제거를 위한 dichloromethane 분배법은 2회 분 배로 선정하였다.

액-액 분배과정을 통해 대부분의 불순물 및 비극성 간섭물질 이 제거될 것으로 판단되지만, 농산물에 따라서 시료로부터 유 래되는 다양한 불순물이 존재할 수 있으므로 추가적인 정제과 정이 필요할 것으로 판단되어 흡착크로마토그래피에 의한 정제 법을 추가하였다. 흡착크로마토그래피는 잔류농약 분석 시 정제 과정에 많이 사용되는 방법으로, 흡착제에는 silica gel, florisil, alumina 등이 주로 사용된다[51]. 본 연구에서는 florisil을 흡착 제로 선정하여 정제하였다. florisil은 색소성분과 지방성분의 제 거 효과가 뛰어나 다양한 연구에서 사용되는 방법이다[48,49]. 용출용매를 조절하여 azoxystrobin의 회수율을 검토한 결과, acetone : hexane 혼합액 $(2: 8, \mathrm{v} / \mathrm{v}) 20 \mathrm{~mL}$ 로 씻어낸 후 acetone : hexane 혼합액(3:7, v/v) $40 \mathrm{~mL}$ 로 용출하였을 때 azoxystrobin 의 회수율이 $98.9 \%$ 의 수준으로 회수되는 양상을 나타내었으므 로, florisil 흡착크로마토그래피법을 이용한 간섭물질 제거를 위 한 추가정제법으로 이용하였다(Table 4).

\section{검량선 작성}

가지와 상추 중 azoxystrobin의 잔류량을 정량 분석하기 위하여 표준 검량선을 작성하였다. azoxystrobin $(99.8 \%)$ 를 acetone에 용해하여 $1,000 \mathrm{mg} / \mathrm{L}$ 의 stock solution을 만들었으며, 이를 acetone에 희석하여 working solution을 조제하여 $1 \mu \mathrm{L}$ 을 $\mathrm{GC}-$ $\mathrm{ECD}$ 에 주입하였다. 가지의 검량선은 $0.01,0.2,0.4,0.6,0.8$ $\mathrm{mg} / \mathrm{L}$ 의 working solution을 조제하였으며, 상추의 검량선은 $0.01,4,8,12,16 \mathrm{mg} / \mathrm{L}$ 의 working solution을 분석하여 나타난 검량선의 직선성이 0.99 이상인 0.999 로 양호하였다(Figs. 4, 5).

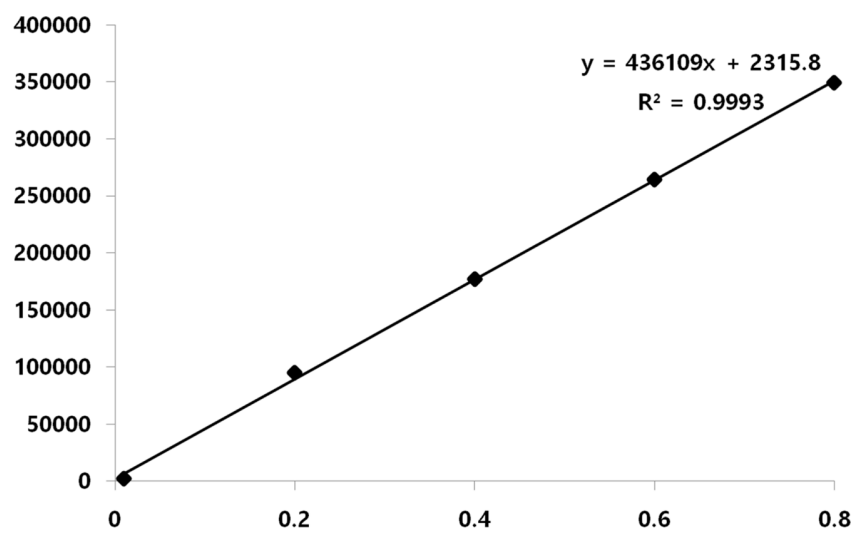

Fig. 4 Standard calibration curves for the quantitation of azoxystrobin in eggplant by GC-ECD

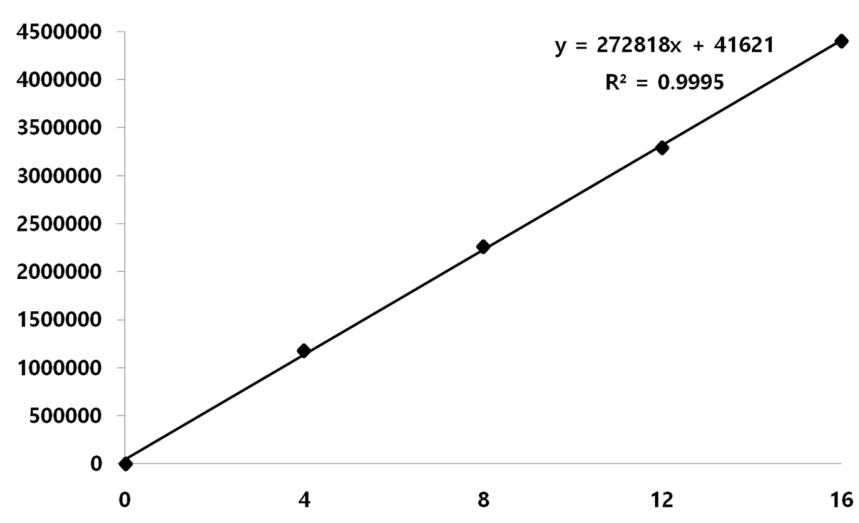

Fig. 5 Standard calibration curves for the quantitation of azoxystrobin in lettuce by GC-ECD

\section{정량한계}

분석기기의 정량한계(LOQ)는 크로마토그램에서 peak로 나타난 대상 성분의 정량적 결과에 신뢰성을 부여할 수 있는 한계농도 로써, 크로마토그램에서 검출된 peak의 signal/noise $(\mathrm{S} / \mathrm{N})$ 비가 최소 10 이상인 성분의 농도를 의미한다[52,53]. 무농약 농산물 시료에서 간섭물질이 존재하지 않음을 확인한 후 분석기기의 정 량한계와 시료량 및 분석과정 중의 농축배율을 계산하여 분석 법의 정량한계를 산출하였다. 가지와 상추 중 azoxystrobin의 최 소 검출량은 모두 $0.1 \mathrm{ng}$ 이었으며, 이를 통해 산출된 분석법의 정량한계는 $0.01 \mathrm{mg} / \mathrm{kg}$ 이었다. 국제기준인 Codex Alimentarius Commission (Codex) 및 식품공전 잔류농약분석법 실무 해설서 에서 권장하는 잔류농약분석법 기준인 $0.05 \mathrm{mg} / \mathrm{kg}$ 이하 또는 허 용기준의 $1 / 2$ 이하의 정량한계 기준에 적합하였다[46].

정량한계 $(\mathrm{mg} / \mathrm{kg})$

$=[$ 기기 정량한계 $(\mathrm{ng}) /$ 주입량 $(\mu \mathrm{L})] \times[$ 시료용액 $(\mathrm{mL}) /$ 시료량 $(\mathrm{g})]$

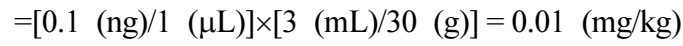

\section{재현성 검중}

기기분석의 안전성 및 분석 재현성 평가를 위해 $0.5 \mathrm{mg} / \mathrm{kg}$ 농 도의 azoxystrobin 표준용액을 10 회 반복 주입하여 얻은 retention time 및 peak area의 변이계수 $(\mathrm{CV}, \%)$ 를 확인하여 재현성을 평 
Table 5 Reproducibility of peak area and retention time of azoxystrobin using GC-ECD

\begin{tabular}{ccc}
\hline \hline Parameter & Retention time $(\min )$ & Peak area $(\mathrm{uV})$ \\
\hline Minimum & 14.205 & 72144 \\
Maximum & 14.267 & 76006 \\
Mean & 14.234 & 74661 \\
SD & 0.02 & 1876.4 \\
CV $(\%)$ & 0.139 & 2.513 \\
\hline
\end{tabular}

*SD: Abbreviations, standard deviation

CV: coefficient of variance

가한 결과, 두 가지 척도에서 최대 $2.5 \%$ 의 오차를 나타내었으 며, 이를 통해 기기분석 시 안정적이고 재현성있는 분석을 수 행할 수 있음을 확인하였다(Table 5).

\section{Azoxystrobin의 회수율 검중}

본 연구에서 azoxystrobin 분석을 위해 확립한 시료의 추출, 정 제 및 기기분석 과정을 농산물 무처리 시료를 이용하여 가지와 상추 중 azoxystrobin의 회수율 실험을 진행하였다. 농산물 무 처리 시료에 azoxystrobin 표준용액을 정량한계의 10 배 $(0.1 \mathrm{mg} /$ $\mathrm{kg}), 50$ 배 $(0.5 \mathrm{mg} / \mathrm{kg})$ 와 가공된 가지 시료와 비슷한 농도인 0.05 $\mathrm{mg} / \mathrm{kg}$, 가공된 상추 시료와 비슷한 농도인 $5,12 \mathrm{mg} / \mathrm{kg}$ 의 농도 가 되도록 인위 첨가하였다. 확립된 azoxystrobin 분석법을 이 용하여 각 농산물을 3 반복으로 분석하여 조사한 회수율 결과 를 Table 6에 나타내었다. 정량한계 10배 수준에서는 95.9$109.5 \%$, 정량한계 50 배 수준에서는 $90.3-95.4 \%$, 가지의 0.05 $\mathrm{mg} / \mathrm{kg}$ 수준에서는 $100.7 \%$, 상추의 $5,12 \mathrm{mg} / \mathrm{kg}$ 수준에서 $108.1,84.7 \%$ 의 양호한 회수율을 나타내었다. 본 azoxystrobin 분석법의 회수율은 84.7-109.5\%로 평균 $97.8 \%$ 의 회수율을 보 였고, 분석오차는 최대 $8.5 \%$ 로 조사되었다. 따라서, 처리수준 및 농산물 시료의 종류에 상관없이 회수율 결과가 식품의약품
안전처에서 고시하고 있는 잔류분석기준인 회수율 $70-120 \%$ 범 위와 분석오차 $10 \%$ 이내를 만족하였다[43,51]. 또한, Noh 등의 연구[12]에서는 인삼에 azoxystrobin을 $0.003,0.03,0.5 \mathrm{mg} / \mathrm{kg}$ 이 되도록 처리한 후 회수율 실험을 진행하여 평균 $98.4 \%$ 의 회수 율을 보였고 $\mathrm{CV}$ 는 $2.4 \%$ 미만이라고 보고하였다. $\mathrm{Kim}$ 등의 연 구[54]에서는 상추에 azoxystrobin을 $0.2,1.0 \mathrm{mg} / \mathrm{kg}$ 이 되도록 처리한 후 회수율 실험을 진행하여 평균 $96.4 \%$ 의 회수율을 보 였고 $\mathrm{CV}$ 는 $4.6 \%$ 미만이라고 보고하였다.

\section{가공된 가지의 농약 잔류량 변화 및 가공계수 산출}

가지를 세척, 찜 및 볶음의 조리과정을 수행한 가공품 중 azoxystrobin의 잔류량을 분석한 결과를 Table 7에 나타내었다. 가공 전 가지의 azoxystrobin 잔류량은 $0.2039 \mathrm{mg} / \mathrm{kg}$ 이었다. 흐 르는 물 세척 후 azoxystrobin의 잔류량은 $0.0589 \mathrm{mg} / \mathrm{kg}$, 찜 가 공 후 $0.0652 \mathrm{mg} / \mathrm{kg}$, 볶음 가공 후 $0.0496 \mathrm{mg} / \mathrm{kg}$ 잔류하였다. 농산물 원료에 남아있는 잔류농약이 세척 및 가열 등의 가공과 정에 의해서 잔류량이 감소하는 것을 알 수 있다. 흐르는 물 세 척과정을 수행한 azoxystrobin의 잔류량은 초기 잔류량에 비해 평균 $71.1 \%$ 감소하였으며, 찜 과정 중 시험 농약의 잔류량은 초기 잔류량 대비 평균 $68.0 \%$ 로 감소하였다. 볶음 조리과정 중 시험 농약의 잔류량은 초기 잔류량 대비 평균 $75.7 \%$ 감소하였 다. Azoxystrobin 농약은 볶음 가공단계에서 가장 높은 제거율 을 보였으며, 흐르는 물 세척, 찜 가공 순으로 제거율이 감소하 였다. 가지를 세척한 후 찐 가지의 농약 잔류량이 세척한 가지 의 잔류량보다 높아지는 결과를 보였다. 이 결과는 찜 가공을 통해 무게가 감소되어 잔류량이 높은 결과를 나타낸 것으로 판 단되었다. 또한, azoxystrobin의 지용성이며 휘발성이 낮은 특성 이므로 찜 가공에 의한 농약 감소율이 적을 것으로 판단되었다. Bonnechere 등의 연구[55]에서 deltamethrin을 처리한 시금치를 데치기 가공한 결과, 농축되는 결과를 보였다. 이는 deltamethrin 이 지용성농약이며, 가공을 통해 약 $20 \%$ 의 무게감소로 인한 결

Table 6 Recovery rate of azoxystrobin in eggplant and lettuce

\begin{tabular}{ccccc}
\hline \hline Crop & Fortification $(\mathrm{mg} / \mathrm{kg})$ & Recovery $\pm \mathrm{SD}^{1)}(\%)$ & $\mathrm{CV}^{2}(\%)$ & $\mathrm{LOQ}(\mathrm{mg} / \mathrm{kg})^{3)}$ \\
\hline \multirow{3}{*}{ Eggplant } & 0.05 & $100.7 \pm 8.5$ & 8.5 & \\
& 0.1 & $109.5 \pm 2.6$ & 2.4 & \\
\hline \multirow{2}{*}{ Lettuce } & 0.5 & $90.3 \pm 1.8$ & 2.0 & 0.01 \\
& 0.1 & $95.9 \pm 1.5$ & 1.5 & 1.2 \\
\\
\end{tabular}

${ }^{1)}$ Standard Deviation ${ }^{2)}$ Coefficient of variation ${ }^{3)}$ Limit of quantitation

Table 7 Residual amounts for azoxystrobin in eggplant

\begin{tabular}{cccc}
\hline \hline Processing & residue amount $(\mathrm{mg} / \mathrm{kg})$ Mean $\pm \mathrm{SD}$ & Removal rate $(\%)^{1)}$ & $\mathrm{PF}^{2)}$ \\
\hline Raw eggplant & $0.2039 \pm 0.0012$ & & \\
Washing & $0.0589 \pm 0.0007$ & 71.1 & 0.29 \\
Steaming & $0.0652 \pm 0.0007$ & 68.0 & 0.32 \\
Stir-frying & $0.0496 \pm 0.0018$ & 75.7 & 0.24 \\
\hline
\end{tabular}

${ }^{1}$ Removal rate: (raw product residue-processing residue)/raw product residue $\times 100$

${ }^{2)} \mathrm{PF}$ : Processing Factor 
Table 8 Residual amounts for azoxystrobin in lettuce

\begin{tabular}{|c|c|c|c|}
\hline Processing & residue amount $(\mathrm{mg} / \mathrm{kg})$ Mean $\pm \mathrm{SD}$ & Removal rate $(\%)^{1)}$ & $\mathrm{PF}^{2)}$ \\
\hline Raw lettuce & $12.296 \pm 0.0267$ & & \\
\hline Soaking washing & $3.0267 \pm 0.0607$ & 75.3 & 0.25 \\
\hline Running washing & $7.5133 \pm 1.3008$ & 38.9 & 0.61 \\
\hline Soaking and running washing & $3.9373 \pm 0.097$ & 68.0 & 0.32 \\
\hline Ultrasonic cleaning & $5.7613 \pm 0.8141$ & 53.1 & 0.47 \\
\hline Blanching & $3.2413 \pm 0.4776$ & 73.6 & 0.26 \\
\hline Blanching water & $6.1187 \pm 0.0798$ & & \\
\hline
\end{tabular}

${ }^{1)}$ Removal rate: (raw product residue-processing residue)/raw product residue $\times 100$

2) PF: Processing Factor

과라고 보고하였다. 또한, Zhibo 등의 연구[56]에서도 pyridaben, $\alpha$-cypermethrin, difenthrin, S-fenvalerate, $\gamma$-cyhalothrin으로 처 리한 동부콩을 데치기 가공하여 농약성분이 농축되었으며, 이를 수분 손실로 인해 발생한 것으로 보고하였다. 이러한 연구결과 를 고려하면 본 연구와 유사한 결과이었다. 결과적으로 가지의 세척 및 조리 시 시험 농약의 잔류량이 $68 \%$ 이상 제거되어 농 약에 대한 가공품의 안전성을 확보할 수 있을 것으로 판단된다. 가공계수는 농산물 원료의 잔류량과 가공한 후의 잔류량의 비 를 나타내는 계수로, 수치가 작을수록 농산물의 초기 잔류량 대 비 감소율이 높아짐을 의미한다. 가공에 따른 azoxystrobin의 가 공계수를 Table 7에 함께 제시하였다. 흐르는 물 세척한 가지 의 가공계수는 0.29 이고, 찜 및 볶음 가공한 가지의 가공계수는 $0.32,0.24$ 이었다. 가공단계가 진행될수록 농약의 잔류량이 감소 하는 것을 확인 할 수 있으므로 가지의 가공과정 중 잔류농약 감소에 효과 있는 것을 확인할 수 있다. 가공계수는 찜 > 세척 $>$ 볶음 순으로 가공계수를 나타내어 잔류농약 감소에 볶음이 가 장 효과가 우수하였다.

Radwan 등의 연구[57]에서 profenofos를 처리한 고추, 파프리 카, 가지를 세척 및 가공한 결과, 담금 물 세척으로 $81-99.26 \%$ 로, 평균 $88.5 \%$ 의 감소율을 나타내었으며, 볶음으로 $98.5-100 \%$ 의 감소율을 나타내었다. Profenofos는 $\mathrm{P}_{\mathrm{OW}} 4.44, \mathrm{VP} 0.124$ $\left(25^{\circ} \mathrm{C}\right)$, 비침투성을 나타내는 농약으로 azoxystrobin 보다 지용 성 성질을 나타내지만 휘발성이 강하고 농약성분이 내부로 침 투되지 않아 세척과 볶음 가공을 통해 많은 양이 제거되는 것 으로 판단된다. Kaushik 등[58]은 병아리콩 낟알저장을 위하여 MRL 이하로 살포한 deltamethrin의 경우 초기잔류량은 0.051 $\mathrm{mg} / \mathrm{kg}$ 이었으나 세척 후 찜 가공하여 완전히 제거하였다고 보고 하였다. Deltamethrin은 $\mathrm{P}_{\mathrm{OW}} 4.7, \mathrm{VP} 1.24 \times 10^{-5}\left(25^{\circ} \mathrm{C}\right)$, 비침 투성 살충제로 지용성을 나타내는 농약이지만 세척 및 찜 가공 을 통해 완전히 제거되어 본 연구의 농약과 특성의 차이를 나 타내지만, 전반적인 감소경향은 유사한 결과를 나타내었다.

\section{가공된 상추의 농약 잔류량 변화 및 가공계수 산출}

상추를 담금 물 세척, 흐르는 물 세척, 담금 후 흐르는 물 세 척, 초음파 세척, 데치기의 조리과정을 수행한 후 azoxystrobin 의 잔류량을 분석한 결과를 Table 8 에 나타내었다. 가공 전 상 추의 azoxystrobin 잔류량은 $12.296 \mathrm{mg} / \mathrm{kg}$ 이었다. 담금 물 세척 후 azoxystrobin의 잔류량은 $3.0267 \mathrm{mg} / \mathrm{kg}$, 흐르는 물 세척 후 $7.5133 \mathrm{mg} / \mathrm{kg}$, 담금 후 흐르는 물 세척 후 $3.9373 \mathrm{mg} / \mathrm{kg}$ 잔류
하였다. 초음파 세척한 상추의 azoxystrobin 잔류량은 5.7613 $\mathrm{mg} / \mathrm{kg}$ 이었으며, 데치기한 상추는 $3.2413 \mathrm{mg} / \mathrm{kg}$, 데치기에 사용 한 물의 azoxystrobin 잔류량은 $6.1187 \mathrm{mg} / \mathrm{kg}$ 이었다. 상추의 세 척과정을 수행한 azoxystrobin의 잔류량은 각각 초기 잔류량에 비해 평균 $58.8 \%$ 감소하였으며, 데치기 가공한 시험농약의 잔 류량은 초기 잔류량 대비 평균 $73.6 \%$ 감소하였다. 담금 물 세 척한 상추의 감소율은 $75.3 \%$, 흐르는 물 세척은 $38.9 \%$, 담금 후 흐르는 물 세척은 $68.0 \%$, 초음파세척은 $53.1 \%$ 의 잔류농약 이 제거되었다. 농약제거 효과는 담금 물 세척 > 담금 후 흐르 는 물 세척 > 초음파 세척 > 흐르는 물 세척 순으로 나타났으며, 담금 물 세척이 가장 우수한 농약 감소율을 나타내었다. 이론 적으로 흐르는 물 세척이 가장 잔류농약 제거가 우수할 것으로 생각되었으나 흐르는 물 세척은 물이 시료 표면에 닿는 시간이 짧고 고르지 않아 잔류농약 제거 효과가 적었던 것으로 판단되 었다. 담금 후 흐르는 물 세척은 $68 \%$ 의 감소율을 나타내었지 만, 담금 물에서 저어가면서 세척할 때 $75.3 \%$ 로 잔류농약 제거 효과가 더 우수하였다. 상추의 담금 물 세척은 1 분 침지 후 30 초 동안 2 회 세척하였으며, 담금 후 흐르는 물 세척은 1 분 침 지 후 흐르는 물에 앞, 뒷면을 3초 세척하여 세척방법에 차이 를 나타내었다. 세척방법의 차이로 인하여 담금 물 세척이 담 금 후 흐르는 물 세척보다 제거 효과가 높은 것으로 판단되었 다. Seo 등의 연구[59]에서 침지세척과 흐르는 물 세척, 이중 세척에 의한 깻잎의 세척 결과를 비교한 결과, 1 회 침지 후 5 초 세척한 방법과 침지 2회 세척한 방법이 거의 유사한 세척률 을 보였으며 침지 2회 세척이 제거량이 조금 더 높았다.

데치기 과정 중 azoxystrobin의 잔류량은 초기 잔류량에 비해 평균 $73.6 \%$ 감소하였다. 이는 데치기 과정을 진행하면서 시험 농약이 물로 이행되고 일부 농약은 가열처리로 인해 소실되는 것으로 판단되었다. 본 실험은 데치기 효과만을 비교하기 위하 여 세척과정을 진행하지 않고 비교 실험한 결과이다. 따라서, 실제 가정에서 엽채류를 조리할 경우 데치기 전에 세척과정을 거치고 가공하기 때문에 대부분의 잔류농약이 제거될 것이다.

가공계수의 수치가 작으면 농산물의 초기 잔류량 대비 감소 율이 높아졌다는 것을 의미한다. 따라서 가공에 따른 상추의 azoxystrobin 가공계수를 Table 8에 함께 나타내었다. 담금 물 세척한 상추의 가공계수는 0.25 , 흐르는 물 세척은 0.61 , 담금 후 흐르는 물 세척은 0.32 , 초음파세척은 0.47 , 데치기는 0.26 의 가공계수가 산출되었다. 담금 물 세척이 가장 낮은 가공계 수를 나타내어 흐르는 물 세척 > 초음파 세척 > 담금 후 흐르는 
물 세척 > 데치기 > 담금 물 세척 순으로 가공계수를 나타내었 다. 결과적으로 상추는 세척만으로도 시험농약의 잔류량이 평균 $60 \%$ 가까이 제거되었다. 채소류의 잔류된 농약은 세척이나 조 리과정에 대부분 제거되어 섭취 시 안전성을 확보할 수 있을 것으로 판단된다.

Kim과 Lee[25]는 결구배추 겉잎을 수세 및 데치기 가공을 통 한 chlorantraniliprole의 잔류량 변화를 연구하였다. 수세와 데치 기 가공으로 산출된 가공계수는 $0.16,0.02$ 으로 수세 후 데치기 시 배추 겉잎에 잔류된 농약은 각각 $84 \%$ 와 $98 \%$ 가 제거되었다. 일반적으로 $\mathrm{P}_{\mathrm{OW}}$ 는 3.5 이상이면 지용성 농약으로 분류되고 있 다. Chlorantraniliprole의 $\mathrm{P}_{\mathrm{OW}}$ 는 2.76으로 지용성 농약의 특성을 나타내고 있지만, 물을 사용하여 세척할 경우에도 상당량의 잔 류물이 제거될 수 있었다. Kim의 연구[32]에서 azoxystrobin을 살포한 미나리를 수돗물, 베이킹소다용액, $0.1 \%$ 세제용액으로 세척한 후 잔류량을 비교하였다. 세제로 세척하면 각각 수확 당 일 $85.35 \%$ 와 수확 후 14 일차 $57.06 \%$ 의 농약이 제거되었고, 베 이킹소다로 세척하면 수확 당일에는 $86.45 \%$, 수확 후 14 일차에 는 $53.44 \%$ 가 제거되었으며, 물로 세척하면 수확 당일에는 $84.97 \%$, 수확 후 14 일차에는 $64.67 \%$ 가 제거되었다. 이 결과들 을 바탕으로 농약 살포 후 시일이 경과될수록 농약의 제거율이 감소하는 경향을 나타내고 있으나, 세제용액, 수돗물, 베이킹소 다 용액의 세척 방법에 따른 농약 제거율은 큰 차이가 없는 것 으로 판단된다. 채소류는 물 세척만으로도 많은 양의 농약이 제 거될 수 있었으며, 본 연구의 가지와 상추에 대한 세척 연구결 과와 유사한 양상을 보였다. 또한, 채소류의 가공 과정 중에서 도 잔류농약 감소에 효과가 있는 것을 확인할 수 있었다.

\section{초 록}

본 연구는 azoxystrobin 농약을 가지와 상추에 처리한 후 세척 및 조리과정 중 농약의 잔류량 변화를 조사하기 위해 수행하였 다. 가지는 흐르는 물 세척, 찜, 볶음으로 가공하였으며, 상추는 담금 물 세척, 흐르는 물 세척, 담금 후 흐르는 물 세척, 초음 파세척, 데치기로 가공하였다. Azoxystrobin의 GC분석의 정량 한계는 $0.01 \mathrm{mg} / \mathrm{kg}$ 이었으며, 회수율은 $84.7-109.5 \%$ 이었다. Azoxystrobin을 살포하여 수확한 가지의 농약 잔류량은 0.204 $\mathrm{mg} / \mathrm{kg}$, 상추의 잔류량은 $12.296 \mathrm{mg} / \mathrm{kg}$ 이었다. 가지의 흐르는 물 세척, 세척 후 찌기, 세척 후 볶기의 잔류량은 $0.059,0.065$, $0.05 \mathrm{mg} / \mathrm{kg}$ 이었다. 상추의 담금 물 세척, 흐르는 물 세척, 담금 후 흐르는 물 세척, 초음파세척, 데치기의 azoxystrobin의 잔류 량은 각각 $3.027,7.513,3.937,5.761,3.241 \mathrm{mg} / \mathrm{kg}$ 이었다. 가 지와 상추의 azoxystrobin 농약의 가공계수 및 감소율을 산출한 결과는 다음과 같았다. 가지의 경우, 흐르는 물 세척의 가공계 수 및 감소율은 $0.29,71.1 \%$, 찜 가공한 가지는 $0.32,68.0 \%$, 볶음 가공한 가지는 $0.24,75.7 \%$ 이었다. 상추의 경우, 담금 물 세척한 상추의 가공계수 및 감소율은 $0.25,75.3 \%$, 흐르는 물 세척은 $0.61,38.9 \%$, 담금 후 흐르는 물 세척은 $0.32,68.0 \%$, 초음파세척은 $0.47,53.1 \%$, 데치기는 $0.26,73.6 \%$ 이었다. 가지 와 상추 중 잔류농약은 세척 및 조리가공을 통해서 잔류농약 감소에 효과가 있는 것을 확인할 수 있었으며, 세척 후 조리과 정을 진행할 시, 대부분의 농약이 제거됨을 확인하였다. 따라서,
세척 및 가공 후 azoxystrobin 가공계수를 위해 평가에 기초자 료로 제공할 수 있을 것이다.

Keywords 가공계수 · 가지 - 상추 - 아족시스트로 - 잔류농약

감사의 글 이 논문은 2017년도 대구대학교 학술연구비 지원에 의하여 수행 되었습니다.

\section{References}

1. Chung HW, Ha YG, Im MH, Shin JE, Do JA, Oh JH, Cho JH, Kwon KS, Park SH (2011) Establishment of 22 pesticide MRLs in agricultural products based on risk assessment. Korean J Environ Agric 30: 166-172

2. 'Pesticide', Doopedia, https://terms.naver.com/entry.nhn?docId=1077737 $\&$ cid $=40942 \&$ categoryId $=31874$

3. Kim SH (2013) Residual Characteristics and Processing Factors of Difenoconazole and Pymetrozine in Water Celery. Dissertation, Chungbuk Nat. University.

4. Lee YD. Hemophilia Life[Website]. 2018, July 26. Retrieved form http:// www.hemophilia.co.kr/news/articleView.html?idxno=5678

5. Nam MJ, Chung DY, Shim WB, Chung DH (2011) Hazard Analysis for the Application of Good Agricultural Practices(GAP) on Paprika During cultivation. J Fd Hyg Safety 26(3): 273-282

6. Lee JK, Woo HD (2010) Current status for management of pesticide maximum residue limits in foods. Korean J Food Sci Technol 43: 2-23

7. FAO, WHO (2015) CODEX alimentarius commission procedural manual. Food and Agriculture Organization, World Health Organization, Rome

8. MFDS (2018) Food standard and specification. Ministry of Food and Drug Safety, Cheongju, Korea 35-36: 494-503

9. Im MH, Ji YJ (2016) A review on processing factors of pesticide residues during fruits processing. J Appl Biol Chem 53(3): 189-201

10. Park SY, Park KS, Im MH, Choi H, Chang MI, Kwon CH, Kim SG, Lee HK, Hong MK, Shim JH, Kim JH (2009) Studies for the processing factors of pesticides during the milling of wheat grain. Korean J Pest Sci 13: 70-78

11. Park SY, Kang HR, Ko KY, Gil KH, Im MH, Lee KS (2009) On the Processing and Reduction Factors of Several Pesticides with Welsh Onion. Korean J Pest Sci 13(4): 249-255

12. Noh HH, Lee JY, Park SH, Lee KH, Oh JH, Im MH, Kyung KS (2012) Residual characteristics of azoxystrobin and difenoconazole in ginseng. Korean J Pest Sci 16: 131-136

13. Kim JG, Kim SS, Park HR, Ji KY, Lee KH, Ham HJ, Im MH, Hur JH (2009) Residues of azoxystrobin during cultivation and processing of ginseng. Korean J Pest Sci 13(4): 232-240

14. Noh HH, Lee KH, Lee JY, Lee EY, Park YS, Park HK, Oh JH, Im MH, Lee YJ, Baeg IH, Kyung KS (2012) Residual characteristics and processing factors of difenoconazole in Fresh ginseng and processed ginseng products. Korean J Pest Sci 16: 35-42

15. Lee JY, Noh HH, Lee KH, Park HK, Oh JH, Im MH, Kwon CH, Lee JK, Woo HD, Kwon KS, Kyung KS (2012) Processing factors of azoxystrobin in processed ginseng products. Korean J Pest Sci 16: 222229

16. Lee EY, Noh HH, Park YS, Kang KW, Lee KH, Park HK, Kwon CH, Im MH, Kyung KS (2009) Processing and reduction factors of pesticide residues in chinese matrimony vine and jujube by drying. Korean J Pest Sci 13: 159-164

17. Im MH, Kwon KI, Park KS, Choi DM, Chang MI, Jeong JY, Lee KJ, Yun MK, Hong MK, Woo GJ (2006) Study on reduction factors of residual pesticides in processing of ginseng. Korean J Pest Sci 10: 22-27

18. Im MH, Kwon KI, Park KS, Lee KJ, Chang MI, Yun WK, Choi WJ, Yoo KS, Hong MK (2007) Reduction rate of azoxystrobin, fenhexamid 
and cyprodinil during ginseng processing. Korean J Food Sci Technol 39: $575-579$

19. Park KS, Choi JH, Suh JH, Kim SG, Lee HK, Shim JH (2009) Studies on the Processing Factors of Pesticides in Dried Carrot from Field Trial and Dipping Test. Korean J Pest Sci 13(4): 209-215

20. Noh HH, Kang KW, Park HK, Lee KH, Lee JY, Lee EY, Park YS, Kyung KS (2010) Processing and Reduction Factors of Azoxystrobin and Flutolanil in Garlic by Freeze-Drying. Korean J Pest Sci 14(3): 235 240

21. MFDS (2018) Korean Food Standards Codex. Pesticide MRLs. Ministry of Food and Drug Safety, http://www.foodsafetykorea.go.kr/foodcode/ index.jsp

22. KHIDI (2017) National Food \& Nutrition Statistics. Korea Health Industry Development Institute, https://www.khidi.or.kr/kps/dhraStat/ result1?menuId=MENU01652\&gubun=age1\&year=2017

23. KHIDI (2016) National Food \& Nutrition Statistics I: based on 2014 Korea National Health and Nutrition Examination Survey

24. Lee YJ (2013) Risk assessment of pesiticide residues in grinseng and processed ginseng products considering the processing factors of pesiticides. Dissertation, Chungnam Nat. University

25. Kim JY, Lee MG (2014) Residue Levels of Chlorantraniliprole and Ethaboxam in Different Parts of a Head-type Korean Cabbage and Reduction of Residues in Outer Leaves by Water Washing and Heattreatment. Korean J Pest Sci 18(4): 330-335

26. Ryu JS (2017) Residual Characteristics of Triazole Rungicides during Cultivation period and Processing of Korean Cabbage. Dissertation, Kyungpook Nat. University

27. Lee HD, You OJ, Ihm YB, Kwon HY, Jin YD, Kim JB, Kim YH, Park SS, Oh KS, Ko SL, Kim TH, Noh JG, Chung KY, Kyung KS (2006) Residual Characteristics of some Pesticides in/on Pepper Fruits and Leaves by Different Types, Growing and Processing Conditions. Korean J Pest Sci 10(2): 99-106

28. Noh HH, Lee JY, Kim JC, Jeong OS, Kim HS, Lee YH, Choi JH, Om AS, Hong SM, Paik MK, Kim DH, Kyung KS (2013) Processing Factor of Matrine in Chili Pepper. Korean J Pest Sci 17(4): 244-248

29. Lee MG, Kim JS (2016) Pesticide residues in chili pepper seeds and their transfer into the seed oil. Korean J Food Sci Technol 48(4): 317-322

30. Park MR (2010) A study on removal efficiency of residual pesticides in vegetables(agricultural products) by washing methods. Dissertation, Kyungwon University

31. Jung HH (2016) Residual Characteristics of triazole pesticides in spinach during cultivation and cooking process. Dissertation, Kyungpook Nat. University

32. Kim IK (2017) Studies on pesticide tolerance limits in minor vegetable crops. Dissertation, Chonnam Nat. University

33. Park KS (2009) Studies for the processing factors of pesticides during the drying and processing of raw agricultural commodities. Dissertation, Chonnam Nat. University

34. Itoiz ES, Fantke P, Juraske R, Kounina A, Vallejo AA (2012) Deposition and residues of azoxystrobin and imidacloprid on greenhouse lettuce with implications for human consumption. Chemosphere 89: 1034-1041

35. Camara MA, Barba A, Cermeno S, Martinez G, Oliva J (2017) Effect of processing on the disappearance of pesticide residues in fresh-cut lettuce: Bioavailability and dietary risk. Journal of environmental science and health 52(12): 880-886

36. Fenoll J, Hellin P, Camacho MM, Lopez J, Gonzalez A, Lacasa A, Flores P (2008) Dissipation rates of procymidone and azoxystrobin in greenhouse grown lettuce and under cold storage conditions. Intern $\mathrm{J}$ Environ Anal Chem 88(10): 737-746

37. A A.Z. Rodrigues, M E. L. R. De Queiroz, A F D Oliveira, AA Neves, F F. Heleno, L Zambolim, J F. Freitas, E H. C Morais (2017) Pesticide residue removal in classic domestic processing of tomato and its effects on product quality. Journal of environmental science and health, part $b$ $0(0): 1-8$

38. Ko HJ, Sun TY, Han JA (2016) Nutritive and Antioxidative Properties of
Eggplant by Cooking Conditions. J Korean Soc Food Sci Nutr 45(12): 1747-1754

39. Park MR, Han JS, Choi SK, Byun GI, Suh BS, Choi SH, Nobuyuki Kozukue (2006) The Changes on Ascorbic Acid and Glycoalkaloid Contents of Eggplant by Parts and Cooking Methods. Culinary Science \& Hospitality Research 12(4): 247-258

40. Korean Crop Protection Association (2017) Guidance Document of Crop Protection Products(Pesticide), Seoul, Korea

41. Yu JH, Choi GJ, Kim HT (2008) Effect of Foliar Uptake of Azoxystrobin and Kresoxim-methyl on Fungicidal Activity against Cucumber Powdery Mildew. J Appl Biol Chem 51(1): 108-113

42. MFDS: A Research of Pesticide Inspection for Safety Management of Imported Foods, 2017

43. Turner JA (2015) The Pesticide Manual A World Compendium Seventeenth Edition. BCPC, Alton, Hampshire UK

44. MFDS (2001) Studies to Imporove the Tolerance Setting System of Pesticide Residues in Foods

45. MFDS Pess Release (April 22, 2008), ${ }^{\circledR}$ How can you effectively remove pesticides from vegetables and fruits $₫$, Chungbuk

46. MFDS (2017) Practical commentary of Residual Pesticide Analysis Method in Food Code, 5th ed., MFDS, Chungbuk

47. Ahn, KG, Kim GH, Kim GP, Kim MJ, Hwang YS, Hong SB, Lee YD, Choung MG (2014) Determination of amisulbrom residues in agricultural commodities using HPLC-UVD/MS. Korean J Pest Sci 18(4): 321-329

48. Choung MG (2019) Simultaneous Analysis of Eight Kinds of Organophosphorus Pesticides for Inspection of Residual Pesticides in Import-Export Agricultural Products. J Korean Soc Int Agric 31(2): 150163

49. AOAC (2000) Pesticide and industrial chemical residues, In Official method of analysis, pp. 1 88. 17th ed., AOAC International, Arlington, VA, USA

50. Lee JH, Park HW, Keum YS, Kwon CH, Lee YD, Kim JH (2008) Dissipation pattern of boscalid in cucumber under greenhouse condition. Korean J Pest Sci 12(1): 67-73

51. Choung MG (2019) Development of Analytical Method for Valinamide Carbamate Fungicide Inprovalicarb Residue. J Korean Soc Int Agric 31(1): 25-33

52. Fong WG, Moye HA, Seiber JN, Toth JP (1999) Pesticide Residues in Food: Methods, Technologies and Regulations, pp. 3-4, 40-44, Canada

53. Miller JM (2005) Chromatography : Concepts and contrasts, pp. 286287. 2nd ed. USA

54. Kim MG, Hwang KW, Hwang EJ, Yoo SC, Moon JK (2017) Absorption of soil residual azoxystrobin to lettuce. J Appl Biol Chem 60(4): 343349

55. Bonnechere A, Hanot V, Jolie R, Hendrickx M, Bragard C, Bedoret T, Loco JV (2012) Effect of household and industrial processing on levels of five pesticide residues and two degradation products in spinach. Food Control 25: 397-406

56. Zhibo H, Zhi X, Wayne J, Zhiqiang C, Jinhui L (2015) Effect of Chinese traditional cooking on eight pesticides residue during cowpea processing. Food Chemistry 170: 118-122

57. Radwan MA, Abu-Elamayem MM, Shiboob MH, Abdel-Aal A (2005) Residual behaviour of profenofos on some field-grown vegetables and its removal using various washing solutions and household processing. Food and Chemical Toxicology 43: 553-557

58. Kaushik G, Satya S, Naik SN (2009) Food processing a tool to pesticide residue dissipation ${ }^{\circ} \mathrm{C}$ A review. Food Research International 42(1): 2640

59. Seo JM, Kim JP, Yang YS, Oh MS, Chung JK, Shin HW, Kim SJ, Kim ES (2007) The Degradation Patterns of Three Pesticides in Perilla Leaf by Cultivation, Storage and Washing. J Fd Hyg Safety 22(3): 199-208

60. National Agriicultural Products Quality Management Service and National Institute of Agriicultural Science (2012) Test Manual for Pesticide Persistence, Gyeongbuk 